\title{
ITGAE wt Allele
}

National Cancer Institute

\section{Source}

National Cancer Institute. IT GAE wt Allele. NCI Thesaurus. Code C107129.

Human IT GAE wild-type allele is located in the vicinity of $17 \mathrm{p} 13$ and is approximately 87 $\mathrm{kb}$ in length. This allele, which encodes integrin alpha-E protein, is involved in cell adhesion and may play a role in activation of intestinal intraepithelial lymphocytes. 